\title{
The use of Social Networks by the Students of a Mexican Public University
}

\author{
Juan Ignacio Barajas Villarruel, María Gregoria Benítez Lima, Ricardo Noyola \\ Rivera and Juan Manuel Buenrostro Morán \\ Facultad de Contaduría y Administración, \\ Universidad Autónoma de San Luis Potosí \\ San Luis Potosí, México
}

\begin{abstract}
The purpose of this study was to determine the relation between the students' use of digital social networks and the variables of age, time, gender, reasons and their Bachelor's Degree program, in the context of the Faculty of Accounting and Administration (FAA) at a Mexican public university (MPU).The specific objectives were: determine the places and devices used to access their preferred digital social networks; their use and motivations to use these tools. The design of the research was non-experimental with a correlational quantitative focus. An instrument was designed, validated and applied to 842 students of a population of 3670. A descriptive analysis was done and, Spearman's Rho, ANOVA and student's t tests were applied. The results determined that Facebook is the most popular social network, followed by YouTube; the main significant reason was leisure. Also there is no influence among the age of the students of the FAA and the time that they spend on digital social networks; the gender of the participants does influence the reasons why they take part in the digital social networks. Furthermore, neither their BA programs, nor the reasons why they take part in the networks, influence the type of digital social networks they use.
\end{abstract}

Keywords: ICTs, Digital Social, Digital Social Networks, Users, Higher Education, Web 2.0.

\section{Introduction}

One of the main changes in education is the use of Information and Communication Technologies (ICTs) in the teaching-learning processes; which have modified the forms of interaction between the students and their classmates as well as teachers. Prensky (2001) considers that students think and process information in a significantly different way from their predecessors and named them the "Digital Natives" generation. Also, Gardner and Davis (2014) identify them as the "App Generation", as they believe this age group masters a 
digital language; thus, it can be said that this situation calls for innovation in terms of the educational processes.

On the other hand, in the case of higher level students, influence of the Internet technological tools, has been determining. Thus, Gómez, Roses and Farías (2012) state that all applications or social media, which emerged from the 2.0 web, including the digital social networks, suppose the active participation or users, who in turn become producers and recipients. These authors also determined that the academic use of the digital social networks is low, and that the students use them for clarification of school assignments and questions from the class, and for activities during their lessons.

Furthermore to this, Richmond, Rochefort and Hitch (2011) noted there is a limited impact of the digital social networks, in the current formal teaching. They deduce it is possible that traditional formal teaching is deeply rooted in Universities. Also, Herrera (2014) pointed out social networks are indeed being utilized in the university context as a mean of interaction and communication due to its ubiquity and immediacy, he added that students do not only share pictures, videos, ideas, etc., but also use them to coordinate their assignments, distribute materials and school documents.

Results of the study carried out by Herrera (2014) on the use of Information and Communication Technologies (ICTs) for school tasks and socialization, showed that $98 \%$ of students belonged to a particular digital social network, and Facebook turned out to be the most popular one.

A study was carried out in the Faculty of Accounting and Administration (FAA) at a Mexican Public University (MPU). The Faculty has 3698 undergraduate students and there are 298 students enrolled in graduate programs. Based on the most recent institutional report, students of this Faculty constantly demand the use of ICT, more particularly access to web 2.0 technological tools, such as digital social networks (Villar, 2016).

Furthermore, the University authorities of the FAA, where this case study was conducted, have established an Institutional Development Plan 2013-2023 (PIDE 2013-2023), which states the comprehensive actions the University must carry out on the basis of the definition of policies, institutional programs, objectives and strategies (UASLP, 2013). In this regard, the PIDE's strategies that justify this study are: a) Increased use of ICTs in order to support the educational processes of the academic institutions and, b) Improvement and innovation of the teaching practice (UASLP, 2013).

In accordance to what have been said and considering that students access to digital social networks in the FAA, the research problem of this study is the lack of information on students' use of digital social networks; also, in order to enable a greater interpretation of the research problem, three variables were taken into consideration: age, gender and the BA program they study as there is not information about the influence of such variables in terms of the time they spend 
using the digital social networks and the reasons why they used them. This information will allow us to define an instructional design proposal that includes the use of digital social networks for academic purposes, aligned with the context of the BA programs of the Faculty and according to the institutional policies of the University.

\section{Social networks}

Social networks are defined as a delimited set of elements or members which can be individuals, groups, organizations, communities, global societies and others (Lozares, 1996). The members of these groups relate to each other based on compatibility.

On the other hand, Castell (2009) defined social networks as "... a set of nodes which are interconnected and can have greater of less relevance for the network in such a way that the particularly important ones are denominated Centers" (p.39). Hence, social networks represent a space of communication that is generated by interconnected nodes.

Furthermore, Vidal, Niurka and Hernández (2013) pointed out that social networks are a structure built by an open system of permanent construction, which involves people who are related by some similar reasons, needs and/or problems; based on principles of sharing, collaboration and creation.

The concept of social network used in this study was built based on the definition provided by Castell (2009), it is then understood as a set of at least two nodes which are interconnected (people, groups, institutions, etc.) through a mean of communication in which members relate to one another and whose relationships can have greater or less relevance.

\section{Digital social networks}

Digital social networks started with the use of Internet, and are part of web 2.0 technologies (Sandoval, Gómez, Demuner, 2012). According to Valenzuela (2013) Friendster and Xing are among the first sites that fostered friends' networks and they appeared between 2001 and 2002; later in 2003 MySpace, LinkedIn y Facebook started.

Initially, digital social networks were focused on entertainment and socialization; however, Islas and Arribas (2010) explained that "subsequent revisions enabled them to start implementing useful functions of linking and social bond, which was fertile ground for the development of social networks based on collective intelligence of active groups and prosumers" (p.153), this means the fusion between producer and consumer; thus, public information was generated, and the "prosumers took the primary role in the information and knowledge society" (p.154).

There is a great diversity of digital social networks; Islas and Arribas (2010) classified them as follows: (a) professional purposes (b) innovation purposes, (c) 
intended for community service, (d) for virtual socialization (e) entertainment and (f) educational contexts.

The concept of social network used in this study is based on the definition provided by Castell (2009), and it is as follows: a set of nodes interconnected via Internet, which enhances communication and interaction of members of a virtual community with a common interest, through technological tools built into a virtual platform.

\section{Related studies}

A diversity of research shows the growth of the social networks on internet, on all social areas and the use they give them; specifically in the case of young university students, the use give the networks is of entertainment, communication, and interaction (Horgan y Sweeney, 2012). The study carried out by Gómez, Roses and Farías (2012) focused on "the university students academic use of social networks; results showed...students make intensive use of social networks as they are part of their life and daily tasks -they are essentially connected all day long; however, the academic use of social networks is limited" (p. 6).

Parra (2010) studied the use of digital social networks, within the university students' habits. Main findings of this research showed that "...curiosity and entertainment are the principal reasons for those who visit social networks" (p.206). Also, Kim, Sohn and Choi (2011) examined and compared, motifs of the use of digital social networks, among Northamerican and Korean university students. These authors determined that the main reasons to use digital social networks, on both student groups, was to look for friends and leisure.

Similarly, Turkey (2013) investigated the use of social networks by university students in relation to their gender, type of use, type of cell phone, and type of sites. A questionnaire was administered on sample of 120 university students; the results showed that students use social networks mainly for social purposes and not so much for academic purposes. Furthermore Turkey (2013) the results showed that Facebook was the most common social network among the students. It was further revealed that there was no significant difference in the use of the Internet.

In Mexico, within the National Youth Survey (IMJUVE, 2010), an individual questionnaire was administered to a sample of 29, 787 Mexicans between 12 and 29 years old; it was a representative sample at a state and national level, including six metropolitan areas. The results showed that out of $69.5 \%$ of the participants, $47.1 \%$ use Internet for social networking purposes; $88.2 \%$ use Facebook, only $4.1 \%$ use Twitter and $6 \%$ other social networks. According to these results, "Women and men used Internet mainly for networking purposes; in a lesser degree, they also used Internet to search and receive information; chatting on Facebook is young Mexican's favorite choice of young Mexicans in this study" (p.33). 
Regarding the use of the social networks, "92\% of the Mexicans who have access to Internet, use a digital social network regularly, the remaining $8 \%$ do not visit these sites due to lack of interest and time, and because of data protection reasons" (AMIPCI, 2013, p.19).

\section{Purpose of the Study}

The purpose of this research is to determine the relation between the students' use of digital social networks and the variables of age, time, gender, reasons and their BA program, in the context of the Faculty of Accounting and Administration at a Mexican public university.

This will be done in order to collect evidences that will help build an instructional design proposal that involves the use of digital social networks in this educational context.

\section{Research Questions}

1. Which places and devices are used by the students of the Faculty of Accounting and Administration of a Mexican public university to access digital social networks?

2. Which are the preferred digital social networks of the students of the Faculty of Accounting and Administration of a Mexican public university?

3. How is the use of the digital social networks by the students of the Faculty of Accounting and Administration of a Mexican public university?

4. Which are the reasons why students of the Faculty of Accounting and Administration of a Mexican public university, use the digital social networks?

5. Is there a relation between the age of participants and the time they spend on digital social networks?

6. Is there a relation between the gender of participants and the reasons for using digital social networks?

7. Is there a relation among the participants of a BA program and the type of digital social networks they use?

8. Is there a relation between the participants' BA program and the reasons why they take part in the digital social networks?

\section{Method}

This is descriptive, non-experimental study based on a correlational quantitative approach (Creswell, 2012); parametric statistics Student's t-tests were applied as well as the unidirectional analysis of variance ANOVA; the non-parametric statistics test of the Rho Spearman correlation coefficient was also applied (Hernández, Fernández y Baptista, 2014). The descriptive analysis helped identify the type and use of the social networks used by the FAA' students. On the other hand, the parametric and non-parametric tests showed the existing correlations among the variables of age, time, gender, BA program, type of digital social networks, and the reasons of use of social networks.

The population for the study was composed of 3670 students, who were registered during the 2014-2015 Academic session, in the following BA programs: Public Accounting; Administration; Public Administration; 
Agribusiness; and Strategic Marketing. A stratified sample was used (Hernández et al., 2014), making sure all strata were represented in every BA program. The sample consisted of a total of 450 students, distributed by BA program: 259 of Public Accounting; 348 of Administration; 123 of Public Administration; 64 of Agribusiness, and 48 of Marketing.

The designed questionnaire was named: "Use of Digital Social networks by students of the Faculty of Accounting and Administration of a Mexican public university". It was designed based on the questionnaire of the 17th Survey of the Association for Media Research (AIMC, 2014) in Spain. The ERSD questionnaire was structured into two sections. The first one contains three items that are related to the student's general information. The second section includes the following dimensions: (a) places where they access to digital social networks (4 closed-ended items and one open-ended question) (b) devices they use to access digital social networks (5 closed-ended items and one open-ended question), (c) frequency of use of digital social networks (16 closed-ended items and one openended question), (d) use of digital social networks (12 closed-ended items), (e) activities they perform in the digital social networks (16 closed-ended items) and (f) reasons that drive them to use digital social networks ( 8 closed-ended items). The 61 closed-ended items provided a balanced scale of five answer choices based on the Likert Scale. The instrument was sent via Internet to all students who were registered in the school year; the level of responses exceeded the estimated samples by BA program.

\section{Validation Process.}

The pilot test applied made possible to identify mistakes, correct answer choices and questions; also, Cronbach's Alfa was applied in order to validate the congruence of the 61 instruments' items. Table 1 shows the global results of validation were 0.820 .

Table 1: Validation of instrument with Cronbachs' Alfa

\begin{tabular}{lcc}
\hline Dimensions & $\begin{array}{c}\text { Number of } \\
\text { closed-ended } \\
\text { items }\end{array}$ & $\begin{array}{c}\text { Cronbach's } \\
\text { Alfa }\end{array}$ \\
\hline $\begin{array}{l}\text { Places where they access digital social } \\
\text { networks }\end{array}$ & 4 & .743 \\
$\begin{array}{l}\text { Devices they use to access digital social } \\
\text { networks }\end{array}$ & 5 & .794 \\
$\begin{array}{l}\text { Frequency of use of digital social networks } \\
\text { Use of digital social networks }\end{array}$ & 16 & .864 \\
$\begin{array}{l}\text { Activities they perform in the digital social } \\
\text { networks }\end{array}$ & 12 & .877 \\
Reasons to access digital social networks & 8 & .859 \\
Total & 61 & .790 \\
\hline
\end{tabular}

Source: prepared by the authors 


\section{Results}

Descriptive Analysis. General information of the 842 participants in this study shows the distribution of frequencies of the four-age range. The total and percentage of each range were: $48 \%$ of the participants are between 18 and 19 years old, 39\% between 21 and 23, 10\% between 24 and 26; and 3\% 27 years old or older. Results also show that $36.5 \%$ are men and $63.5 \%$ are women. Regarding their major, 31\% of participants study the BA in Public Accounting, 41\% Public Administration, 15\% Marketing, and 8\% Agribusiness.

Table 2: Places where they access digital social networks

\begin{tabular}{lccccc}
\hline & Never & Sometimes & $\begin{array}{c}\text { Do not attend } \\
\text { regularly }\end{array}$ & $\begin{array}{c}\text { Almost } \\
\text { always }\end{array}$ & Always \\
\hline Home & $4 \%$ & $11 \%$ & $1 \%$ & $23 \%$ & $61 \%$ \\
Work & $25 \%$ & $26 \%$ & $11 \%$ & $23 \%$ & $15 \%$ \\
School & $3 \%$ & $37 \%$ & $11 \%$ & $33 \%$ & $15 \%$ \\
$\begin{array}{l}\text { Internet } \\
\text { café }\end{array}$ & $37 \%$ & $31 \%$ & $18 \%$ & $8 \%$ & $6 \%$ \\
\hline
\end{tabular}

Source: prepared by the authors

Table 2 shows the places where the 842 students access digital social networks, $33 \%$ of participants said they access from the FAA, 23\% from home; $37 \%$ said they never access from an Internet café, and $25 \%$ do not access social networks from their workplace.

Table 3: Devices students use to access digital social networks

\begin{tabular}{lccccc}
\hline & Never & Sometimes & $\begin{array}{c}\text { Do not } \\
\text { attend } \\
\text { regularly }\end{array}$ & $\begin{array}{c}\text { Almost } \\
\text { always }\end{array}$ & Always \\
\hline $\begin{array}{l}\text { Smartphone } \\
\begin{array}{l}\text { Desktop } \\
\text { computer }\end{array}\end{array}$ & $14 \%$ & $6 \% \%$ & $1 \%$ & $22 \%$ & $70 \%$ \\
$\begin{array}{l}\text { Laptop } \\
\text { computer }\end{array}$ & $9 \%$ & $26 \%$ & $7 \%$ & $35 \%$ & $23 \%$ \\
Tablet & $41 \%$ & $23 \%$ & $14 \%$ & $12 \%$ & $10 \%$ \\
Game console & $64 \%$ & $15 \%$ & $12 \%$ & $6 \%$ & $4 \%$ \\
\hline
\end{tabular}

Source: prepared by the authors

The table 3 shows that a $70 \%$ of the participants of the study always access digital social networks from their smartphone; $35 \%$ almost always access from a lap-top; meanwhile $64 \%$, never access from a videogames console. 
Table 4: Digital social networks accessed by students of the FAA

\begin{tabular}{lcccccc}
\hline & Never & Sometimes & Unknown & $\begin{array}{c}\text { Almost } \\
\text { always }\end{array}$ & Always & Unanswered \\
\hline Badoo & $68 \%$ & $7 \%$ & $21 \%$ & $1 \%$ & $1 \%$ & $2 \%$ \\
Facebook & $1 \%$ & $10 \%$ & $1 \%$ & $28 \%$ & $58 \%$ & $2 \%$ \\
Twitter & $44 \%$ & $26 \%$ & $2 \%$ & $16 \%$ & $11 \%$ & $2 \%$ \\
Fotolog & $71 \%$ & $4 \%$ & $20 \%$ & $0 \%$ & $1 \%$ & $3 \%$ \\
Google+ & $20 \%$ & $22 \%$ & $2 \%$ & $25 \%$ & $29 \%$ & $3 \%$ \\
Habbo & $71 \%$ & $4 \%$ & $22 \%$ & $1 \%$ & $0 \%$ & $3 \%$ \\
Hi5 & $78 \%$ & $5 \%$ & $13 \%$ & $1 \%$ & $1 \%$ & $3 \%$ \\
Instagram & $36 \%$ & $8 \%$ & $2 \%$ & $19 \%$ & $19 \%$ & $15 \%$ \\
MySpace & $80 \%$ & $7 \%$ & $8 \%$ & $2 \%$ & $1 \%$ & $3 \%$ \\
Neotlog & $72 \%$ & $2 \%$ & $21 \%$ & $1 \%$ & $0 \%$ & $3 \%$ \\
LinkedIn & $68 \%$ & $7 \%$ & $18 \%$ & $2 \%$ & $1 \%$ & $3 \%$ \\
Pinterest & $61 \%$ & $9 \%$ & $19 \%$ & $4 \%$ & $4 \%$ & $3 \%$ \\
Sonico & $72 \%$ & $4 \%$ & $21 \%$ & $1 \%$ & $0 \%$ & $2 \%$ \\
Tuienti & $70 \%$ & $2 \%$ & $23 \%$ & $1 \%$ & $0 \%$ & $4 \%$ \\
Flickr & $69 \%$ & $4 \%$ & $22 \%$ & $1 \%$ & $1 \%$ & $4 \%$ \\
YouTube & $2 \%$ & $17 \%$ & $1 \%$ & $36 \%$ & $41 \%$ & $3 \%$ \\
\hline Source: & $2 \%$ & & & & $3 \%$ \\
\hline
\end{tabular}

Source: prepared by the authors

Table 4 shows the following results: $58 \%$ of the participants always access Facebook, $41 \%$ YouTube, 29\% Google. Finally 50\% never use networks such as Myspace, Pinterest, Tuenti among others.

Table 5: Favorite social networks of students of the FAA

\begin{tabular}{lc}
\hline Digital social networks & Preference percentage \\
\hline Facebook & $70 \%$ \\
Twitter & $4 \%$ \\
Instagram & $6 \%$ \\
WhatsApp & $10 \%$ \\
YouTube & $7 \%$ \\
Pinterest & $2 \%$ \\
Tumblr & $1 \%$ \\
\hline
\end{tabular}

Source: prepared by the authors 
Table 5 shows about the students preference of social networks. $10 \%$ of the participants said they preferred Whatsapp. Even so, WhatsApp was not considered a social network in this study, but a messaging tool.

Table 6: Students' use of digital social networks

\begin{tabular}{|c|c|c|c|c|c|c|}
\hline & Never & Sometimes & $\begin{array}{c}\text { Unknow } \\
n\end{array}$ & $\begin{array}{l}\text { Almost } \\
\text { always }\end{array}$ & $\begin{array}{c}\text { Alway } \\
\text { s }\end{array}$ & $\begin{array}{c}\text { Unanswere } \\
\mathrm{d}\end{array}$ \\
\hline $\begin{array}{l}\text { Relationships } \\
\text { with friends }\end{array}$ & $68 \%$ & $7 \%$ & $21 \%$ & $1 \%$ & $1 \%$ & $2 \%$ \\
\hline $\begin{array}{l}\text { Family } \\
\text { relationships }\end{array}$ & $1 \%$ & $10 \%$ & $1 \%$ & $28 \%$ & $50 \%$ & $11 \%$ \\
\hline $\begin{array}{l}\text { Relationships } \\
\text { linked to } \\
\text { school }\end{array}$ & $44 \%$ & $26 \%$ & $2 \%$ & $16 \%$ & $11 \%$ & $2 \%$ \\
\hline Hobbies & $71 \%$ & $4 \%$ & $20 \%$ & $0 \%$ & $1 \%$ & $3 \%$ \\
\hline Social events & $20 \%$ & $22 \%$ & $2 \%$ & $25 \%$ & $29 \%$ & $3 \%$ \\
\hline News updates & $71 \%$ & $4 \%$ & $22 \%$ & $1 \%$ & $0 \%$ & $3 \%$ \\
\hline $\begin{array}{l}\text { Rumors at } \\
\text { school }\end{array}$ & $78 \%$ & $5 \%$ & $13 \%$ & $1 \%$ & $1 \%$ & $3 \%$ \\
\hline School news & $36 \%$ & $20 \%$ & $2 \%$ & $19 \%$ & $19 \%$ & $3 \%$ \\
\hline $\begin{array}{l}\text { School } \\
\text { assignments }\end{array}$ & $80 \%$ & $7 \%$ & $8 \%$ & $2 \%$ & $1 \%$ & $3 \%$ \\
\hline Parties & $72 \%$ & $2 \%$ & $21 \%$ & $1 \%$ & $0 \%$ & $3 \%$ \\
\hline $\begin{array}{l}\text { Video } \\
\text { downloads }\end{array}$ & $68 \%$ & $7 \%$ & $18 \%$ & $2 \%$ & $1 \%$ & $3 \%$ \\
\hline File downloads & $61 \%$ & $9 \%$ & $19 \%$ & $4 \%$ & $4 \%$ & $3 \%$ \\
\hline
\end{tabular}

Source: prepared by the authors

Results on Table 6, show the use of social networks; $50 \%$ are used to family related activity; $29 \%$ for social and cultural events; $19 \%$ for school related news. Meanwhile $80 \%$ never use them for school tasks; $78 \%$ for gossiping; $71 \%$ for leisure and hobbies and 71\%, never use them for news updating. 
Table 7: Activities performed by students on the digital social networks

\begin{tabular}{|c|c|c|c|c|c|c|}
\hline & Never & $\begin{array}{l}\text { Few } \\
\text { times }\end{array}$ & Uncertain & Regularly & Always & Unanswered \\
\hline $\begin{array}{l}\text { Comment and } \\
\text { share ideas }\end{array}$ & $6 \%$ & $43 \%$ & $5 \%$ & $34 \%$ & $10 \%$ & $2 \%$ \\
\hline Post photos & $5 \%$ & $45 \%$ & $4 \%$ & $35 \%$ & $9 \%$ & $2 \%$ \\
\hline School assignments & $1 \%$ & $19 \%$ & $4 \%$ & $52 \%$ & $18 \%$ & $6 \%$ \\
\hline $\begin{array}{l}\text { Search for } \\
\text { bibliographic } \\
\text { materials }\end{array}$ & $4 \%$ & $18 \%$ & $9 \%$ & $45 \%$ & $21 \%$ & $3 \%$ \\
\hline $\begin{array}{l}\text { Search for scientific } \\
\text { articles }\end{array}$ & $7 \%$ & $26 \%$ & $14 \%$ & $38 \%$ & $13 \%$ & $2 \%$ \\
\hline Read newspapers & $9 \%$ & $31 \%$ & $12 \%$ & $34 \%$ & $12 \%$ & $3 \%$ \\
\hline $\begin{array}{l}\text { Search for } \\
\text { academic } \\
\text { magazines }\end{array}$ & $12 \%$ & $34 \%$ & $15 \%$ & $28 \%$ & $8 \%$ & $4 \%$ \\
\hline $\begin{array}{l}\text { Take a look at } \\
\text { popular magazines }\end{array}$ & $14 \%$ & $31 \%$ & $14 \%$ & $29 \%$ & $7 \%$ & $3 \%$ \\
\hline Download music & $11 \%$ & $19 \%$ & $7 \%$ & $39 \%$ & $22 \%$ & $3 \%$ \\
\hline Follow singers & $20 \%$ & $28 \%$ & $9 \%$ & $24 \%$ & $15 \%$ & $3 \%$ \\
\hline Follow politicians & $32 \%$ & $26 \%$ & $10 \%$ & $20 \%$ & $9 \%$ & $3 \%$ \\
\hline $\begin{array}{l}\text { Watch music } \\
\text { videos }\end{array}$ & $4 \%$ & $17 \%$ & $5 \%$ & $43 \%$ & $27 \%$ & $4 \%$ \\
\hline $\begin{array}{l}\text { Watch } \\
\text { entertainment } \\
\text { videos }\end{array}$ & $7 \%$ & $22 \%$ & $7 \%$ & $38 \%$ & $22 \%$ & $4 \%$ \\
\hline Share music & $20 \%$ & $33 \%$ & $10 \%$ & $22 \%$ & $11 \%$ & $3 \%$ \\
\hline Share videos & $20 \%$ & $33 \%$ & $8 \%$ & $24 \%$ & $12 \%$ & $3 \%$ \\
\hline Download videos & $29 \%$ & $31 \%$ & $8 \%$ & $18 \%$ & $10 \%$ & $3 \%$ \\
\hline
\end{tabular}

Source: prepared by the authors

Information in table 7 shows the percentage of students' participation in different activities performed on the digital social networks: $27 \%$ watch music videos, $22 \%$ to download music, and $22 \%$ to watch entertainment videos. Data also show that $45 \%$ of participants do not use digital social networks to post photos; $43 \%$ of participants use social networks to place comments, and $32 \%$ of them never use social networks to follow a politician. 
Table 8: Students' reasons to participate in the digital social networks.

\begin{tabular}{lcccccc}
\hline & $\begin{array}{c}\text { Strongly } \\
\text { agree }\end{array}$ & Agree & Neutral & Disagree & $\begin{array}{c}\text { Strongly } \\
\text { disagree }\end{array}$ & Unanswered \\
\hline Entertainment & $3 \%$ & $2 \%$ & $8 \%$ & $49 \%$ & $35 \%$ & $3 \%$ \\
$\begin{array}{l}\text { To facilitate } \\
\text { their learning }\end{array}$ & $3 \%$ & $6 \%$ & $16 \%$ & $47 \%$ & $26 \%$ & $2 \%$ \\
$\begin{array}{l}\text { Curiosity } \\
\text { To stay up-to- }\end{array}$ & $4 \%$ & $6 \%$ & $24 \%$ & $46 \%$ & $17 \%$ & $3 \%$ \\
$\begin{array}{l}\text { date with } \\
\text { social and }\end{array}$ & & $4 \%$ & $21 \%$ & $49 \%$ & $20 \%$ & $3 \%$ \\
$\begin{array}{l}\text { recreational } \\
\text { activities }\end{array}$ & & & & & & $3 \%$ \\
$\begin{array}{l}\text { To stay up-to- } \\
\text { date with news }\end{array}$ & $2 \%$ & $2 \%$ & $12 \%$ & $54 \%$ & $27 \%$ & $3 \%$ \\
$\begin{array}{l}\text { To make } \\
\text { friends }\end{array}$ & $9 \%$ & $12 \%$ & $30 \%$ & $34 \%$ & $11 \%$ & $3 \%$ \\
$\begin{array}{l}\text { To have fun } \\
\text { To relax }\end{array}$ & $3 \%$ & $6 \%$ & $21 \%$ & $48 \%$ & $18 \%$ & $3 \%$ \\
\hline
\end{tabular}

Source: prepared by the authors

Data in table 8 inform about the students' reasons to participate in the digital social networks. Answers show that $54 \%$ of the students use social networks to stay up-to-date with latest news, $49 \%$ for entertainment purposes; $49 \%$ of participants use social networks to stay up-to-date with social and recreational activities; $9 \%$ disagrees on the idea of using social networks to make friends.

Parametric and Non-Parametric Statistics Analysis. The correlational analysis conducted in this study included the relation between the time spent by students on social networks and their age; participants' gender with the reason they use digital social networks; their BA program with the type of social networks they use, and the reasons why they participate in the social networks. The parametric student's t-test was applied for this correlational study, as well as the one-way analysis of variance (ANOVA) and the non-parametric statistics test of Spearman's rank correlation coefficient (Hernandez et al., 2013). 
Table 9: Spearman's Rho correlation coefficient between age and time spent on the digital social networks

\begin{tabular}{lllcc}
\hline & & & \\
& & & & \\
& & $\begin{array}{c}\text { Time spent } \\
\text { on the } \\
\text { networks }\end{array}$ & Age \\
\hline $\begin{array}{l}\text { Rho de } \\
\text { Spearman }\end{array}$ & $\begin{array}{l}\text { Time on the } \\
\text { networks }\end{array}$ & $\begin{array}{l}\text { Correlation } \\
\text { coefficient }\end{array}$ & 1.000 & -.062 \\
& & Sig. (bilateral) &. & .078 \\
& Age & N & 813 & 813 \\
& & Correlation & -.062 & 1.000 \\
& coefficient & & .078 \\
& Sig. (bilateral) & 813 & 842 \\
\hline
\end{tabular}

Source: Prepared by the authors

Table 9 shows the results of the Spearman's Rho correlation coefficient regarding students' age and time spent on the social networks, data show the correlation of -.062 , a significance level of .078 , based on this information it can be said that age does not influence the time students spend on the social networks as the result is higher than the critical level of 0.05 .

Table 10: Student's t-test between participants' gender and reasons to take part in the digital social networks.

\begin{tabular}{|c|c|c|c|c|c|c|c|}
\hline \multicolumn{8}{|c|}{ Independent sample test } \\
\hline & & \multicolumn{4}{|c|}{$t$ - test for equality of means } & \multicolumn{2}{|c|}{ Group statistics } \\
\hline & & $t$ & gl & $\begin{array}{c}\text { Sig. } \\
\text { (bilateral) }\end{array}$ & $\begin{array}{c}\text { Measure } \\
\text { differences }\end{array}$ & Gender & Mean \\
\hline \multirow[t]{2}{*}{$\begin{array}{l}\text { Participation } \\
\text { rate }\end{array}$} & $\begin{array}{l}\text { Equal } \\
\text { variances } \\
\text { assumed }\end{array}$ & 2.271 & 782 & .023 & .10995 & Man & 3.8361 \\
\hline & $\begin{array}{l}\text { Equal } \\
\text { variances } \\
\text { not assumed }\end{array}$ & 2.285 & 604.77 & .023 & .10995 & Woman & 3.7262 \\
\hline
\end{tabular}

Source: prepared by the authors.

Table 10 shows the student's t- test between participants' gender and the reasons why they take part in the digital social networks; findings show that the measure difference of 10995 between men and women was not significant as the 
significance level was 0.023, (below the critical level 0.05), which allows to identify there are differences in terms of gender and the reasons why students participate in the social networks.

Table 11: Relation between the BA programs they study and the type of social network they use.

ANOVA

Type of networks rate

\begin{tabular}{lcccc}
\hline & $\mathrm{N}$ & Mean & $\begin{array}{c}\text { Typical } \\
\text { deviation }\end{array}$ & Sig. \\
\hline BA in Public Accounting & 205 & 1.9918 & 0.62908 & 0.066 \\
BA in Administration & 285 & 2.1077 & 0.60276 & \\
BA in Public Administration & 115 & 1.9832 & 0.46168 & \\
BA in Strategic Marketing & 48 & 2.1784 & 0.52084 & \\
BA in Agribusiness & 55 & 2.0602 & 0.47825 & \\
Total & 708 & 2.055 & 0.57807 & \\
\hline
\end{tabular}

Source: prepared by the authors.

Table 11 shows the results of the ANOVA test, it can be seen that the average maximum by BA program was 2.1784 , and the minimum was 1.9918 ; because the significance analysis got a value of .066 (above the critical level of 0.05 ); this allows us to identify there is no relation between the BA program of students and the type of digital social networks they use.

Table 12: ANOVA test. Relation between the BA programs the study and the reasons why they participate in the digital social networks.

ANOVA

Participation Rate

\begin{tabular}{lcccc}
\hline & N & Mean & $\begin{array}{c}\text { Typical } \\
\text { deviation }\end{array}$ & Sig. \\
\hline BA in Public Accounting & 237 & 3.7542 & 0.60101 & 0.988 \\
BA in Administration & 327 & 3.7764 & 0.6846 & \\
BA in Public Administration & 117 & 3.7895 & 0.58576 & \\
BA in Strategic Marketing & 47 & 3.7633 & 0.80388 & \\
BA in Agribusiness & 59 & 3.75 & 0.71015 & \\
Total & 787 & 3.7689 & 0.65475 & \\
\hline
\end{tabular}

Source: prepared by the authors. 
Table 12 shows results of the ANOVA test in terms of the relation between the BA program the participants study and the reasons why they participate in the digital social networks; these results show that the average maximum was 3.7895 and the minimum 3.75 as the value obtained through the significance analysis was 0.988 (above the critical level of 0.05 ). Such results allow us to identify there is no relation between the BA program in which students are enrolled and the type of digital social networks they use.

\section{Discussion}

Results helped to determine that the majority of students who use digital social networks are in the 18-23 age group. This information is consistent with the results provided by the AMIPCI (2013) regarding the age group and the device users prefer to access digital social networks. Findings also show that women represent the majority of participants who use digital social networks.

On the other hand, the most common places where students access to social networks are: their house, followed by school, work and Internet cafés. In this regard, it is interesting to identify that results suggest the existence of not very conventional places to access social networks such as: shopping centers, parks and or restaurants. In addition, results show that the Smartphone is the main device used to access the social networks, followed by laptops, desktops and tablets. It is important to point out that tablets are not frequently chosen by users as a mean to access social networks, this information is important, especially if we consider that tablets represent a technological trend whose prices seem to be more reasonable than in the past.

Regarding the social networks used by the students of the faculty of Accounting and Administration, and based on the results of the National Youth Survey (2010), AMIPCI (2013), as well as Turkey's (2013), Sánchez, Ruíz and Sánchez (2015) and Domínguez and López (2015), it is evident that the most popular social network among the students who participated in this study is Facebook, followed by YouTube, Instagram and + Google. In this respect, findings made by Quan-Haase and Young (2010) showed that $82 \%$ of university students reported they use Facebook several times a day.

In regard to the use of digital social networks, results helped determine that the majority of participants in this study use social networking mainly to interact with friends or family, they use social networks less frequently to stay up-todate with news and current events, to do homework, and to download academic papers, respectively.

The main activities students do on the digital social networks include watching and downloading music and entertaining videos; they also download bibliographic materials and use social networks to do their homework. On the other hand, the activities that participants do less frequently are: check out academic and popular magazines, follow politicians and singers, and post photos. 
The main reasons to access digital social networks are the ones related to socialization and entertainment as well as recreation. The foregoing coincides with the information of studies conducted by Parra (2010); Gómez, Roses y Farias (2012); Turkey (2013), Sánchez, Rodríguez, Ruíz-Palmero y Sánchez-Rivas (2015) and Domínguez and López (2015), who demonstrated that university students use digital social networks for curiosity and entertainment purposes.

Other results determined that: (a) can be determined: (a) there is not influence between the participants' age and the time they spend on the digital social networks; (b) the BA program of students do not influence the type of social networks they use or the reasons why they participate (c) students' gender does influence their reasons to participate on the social networks.

On the other hand, regarding the contribution of this research to the field of studies on digital social networks in the context of Mexican universities, it is reaffirmed the election of BA programs in economics and administration to conduct studies on digital social networks (Domínguez and López, 2015).

In addition, these authors stated that the majority of these studies were conducted in institutions located in Mexico City, which means this research adds evidence about the uses of social networks in a different context, as it was carried out in a University that is not located in the Mexico City area.

\section{Conclusions}

Based on the previous results, it can be concluded that it is necessary to reconsider the use of digital social networks as technological tools that communicate, organize, relate, value, and share information that supports learning processes of the students at the Faculty of Accounting and Administration. It is recommended to establish a strategic plan about the formal use of digital social networks in the learning process of the FAA, on the bases of the didactic planning (instructional design), teacher education on the use of digital social networks, and multidisciplinary collaboration through these technological tools.

Facebook is the most popular digital social network among students of the FAA followed by YouTube. Consequently, further study is recommended in this area, more particularly on YouTube and its impact on Higher education students.

Another important point is the use of WhatsApp, given its growth trend due to the use of mobile devices such as the smartphone. It is suggested, then to study its potential in the educational context.

It is important to point out that participants in this research were mainly women and, considering the gender variables and the reasons for using social networks, it can be said that there is a relation between such variables, which permits to conclude that women have clear reasons to use digital social networks. This information is confirmed by the studies conducted by Tüfekçi (as cited in Sponcil \& Gitimu, 2011) who points out that women use more social network 
sites than men; also Sheldon (2008) notes that women use social networks to keep in touch with friends and family, and for entertainment purposes.

In addition, the BA program of students does not influence the reasons why they participate in social networks; regardless the BA program, they use them for entertainment and recreational purposes; based on this information it can be concluded that the approach of BA programs does not foster or promote the use of digital social networks for academic activities, thus, there are not limitations for the use of social networks based on the BA program. These results allow us to confirm that positive attitude of students towards technological tools and their great communicative potential are factors that will contribute to include such tools in the educational process if professors integrate them properly in an instructional design process. It can be said then, that giving a new meaning to social networks in the context of education remains as a major challenge.

\section{References}

Asociación Mexicana de Internet (2014). Estudio sobre los hábitos de los usuarios de internet en México 2014. [Study on the habits of Internet users in Mexico 2014]. Retrieved from http://imco.org.mx/telecom_y_tics/estudio-sobre-los-habitos-de-losusuarios-de-internet-en-mexico-2014-via-amipci/.

Asociación para la Investigación de Medios de Comunicación (2014). Navegantes en la Red - Encuesta AIMC a usuarios de Internet. [Navigators on the Internet -AIMC survey on Internet users]. Retrieved from: http://www.aimc.es/-Navegantes-en-laRed-.html.

Castell, M. (2009). Comunicación y poder. [Communication and power]. Madrid: Alianza.

Creswell, J. W. (2012). Educational research: Planning, conducting, and evaluating quantitative and qualitative research (4th ed.). Boston, MA: Pearson.

Domínguez, F. y López, R. (2015). Uso de la redes sociales digitales entre los jóvenes universitarios en México. Hacia la construcción de un estado del conocimiento (2004-2014). [Use of digital social networks among university students in Mexico. Towards the construction of a state of knowledge (2004-2014)]. Revista de Comunicación, vol. 14, pp. 48-69.

Gardner, H. y Davis, K. (2014). La generación app. [ The generation app]. Paidós: España.

Gómez, Marisol, Roses, Sergio y Farías Pedro. (2012). El uso académico de las redes sociales en universitarios. [The academic use of social networks in university students]. Comunicar, vol. 29, no. 38, 2012, pp. 131-138. doi: 10.3916/C38-2011-0304 .

Hernández, R., Fernández, C. y Baptista, L. (2014). Metodología de la Investigación. [Research Methodology]. (6a . Ed.) México: McGrawHill.

Herrera, M. (2014). Las redes sociales como entornos académicos en la enseñanza universitaria. [Social networks as academic environments in university education]. RIDE Revista Iberoamericana para la Investigación y el Desarrollo Educativo. No. 12.

Horgan, A., y Sweeney, J. (2012). University Students' Online Habits and Their Use of the Internet for Health Information. CIN: Computers, Informatics, Nursing, vol. 30 no. 8, pp. 402-408. doi:10.1097/NXN.0b013e3182510703

IMJUVE (2011). Encuesta Nacional de la Juventud 2010. [National Youth Survey 2010]. General Results. Mexican Institute of Youth. Recovered from: http://www.imjuventud.gob.mx/imgs/uploads/Encuesta_Nacional_de_Juvent ud_2010_-_Resultados_Generales_18nov11.pdf

Kim, Y., Sohn, D y Choi, SM. (2011). Cultural difference in motivations for using social 
network sites: a comparative study of American and Korea college students. Computers in human behavior, vol. 27, vo. 1, pp. 365-372. doi:10.1016/j.chb.2010.08.015

Islas, O. y Arribas, A. (2010). Comprender las redes sociales como ambientes mediáticos. [Understand social networks as media environments]. Piscitelli, A., Adaime, I. y Binder, I. (Eds.) El proyecto Facebook y la Posuniversidad. Sistemas operativos sociales $y$ entornos abiertos de aprendizaje. [The Facebook project and the Posuniversity. Social operating systems and open learning environments]. (1a. ed. pp. 147-161) Madrid, España: Ariel y Fundación Telefónica

Lozares, C. (1996). La teoría de redes sociales. [The theory of social networks]. Papers, no. 48, pp. 103-126. doi: 10.5565/rev/ papers/v48n0.1814

Parra, Castrillón Eucario. (2010). Las redes sociales de Internet: también dentro de los hábitos de los estudiantes universitarios. [Internet social networks: also within the habits of university students.]. Anagramas: Universidad de Medellin.

Prensky, M. (2001). Digital natives, digital immigrants. On the Horizon, MCB University Press, vol. 9 no. 5, pp.1-6. doi: 10.1108/10748120110424816

Quan-Haase, A., \& Young, A. L. (2010). Uses and gratifications of social media: A comparison of facebook and instant messaging. Bulletin of Science, Technology $\mathcal{E}$ Society, vol. 30 no. 5, pp. 350-361. doi:10.1177/0270467610380009

Richmond, N.; Rochefort, B. \& Hitch, L.P. (2011). Using Social Networking Sites During the Career Manage- ment Process, in Wankel, L.A \& Wankel, C. (Eds.). Higher Education Administration with Social Media: Including Applications in Student Affairs, Enrolment Management, Alumni Affairs, and Career Centers. Bingley (UK): Emerald.

Sánchez-Rodríguez, J., Ruíz-Palmero, J. Sánchez-Rivas, E. (2015). Uso problemático de las redes sociales en estudiantes universitarios. [Problematic use of social networks in university students]. Revista Complutense de Educación 159 ISSN: 1130-2496 vol. 26 Núm. Especial (2015), pp. 159-174. doi: 10.5209/ rev_RCED.2015.v26.46360

Sandoval, R., Gómez, M. y Demuner, M. (2012). Las redes sociales en las organizaciones. [Social networks in organizations]. Universidad Autónoma del Estado de México: Bonobos.

Sheldon, P. (2008). Student favorite: Facebook and motives for its use. Southwestern Mass. Communication Journal, vol. 23 no. 2, pp. 39-53.

Sponcil, M. \& Gitimu, P. (2011). Use of social media by college students: Relationship to communication and self-concept. Journal of Technology Research, vol. 4, pp. 1-13.

Turkey, Antalya (2013). University students'use of social networks sites and their relations with some variables. WEI International Academic Conference Proceedings January. pp. 14-16.

Universidad Autónoma de San Luis Potosí (2013). Plan Institucional de Desarrollo 20132023. [ Institutional Development Plan 2013-2023]. México: UASLP.

Valenzuela, R. (2013). Las redes sociales y su aplicación en la educación. [Social networks and their application in education]. Revista Digital Universitaria vol. 14 no. 4, pp. 1-14.

Vidal Ledo, María, Vialart Vidal, María Niurka, \& Hernández García, Luis. (2013). Redes sociales. [Social Network]. Educación Médica Superior, vol. 27 no. 1, pp. 146-157.

Villar, F. (2014). Informe de Trabajo 2013-2014. [Working report 2013-2014.]México: UASLP 